\title{
5 Russia and Mt. Athos (1878-1914)
}

Russia, through its ecclesiastical efforts in the Ottoman Empire, sought to establish closer ties with the Orthodox population while strengthening Russian influence in the eastern Mediterranean as a whole. Mt. Athos, a collection of monasteries situated on a small peninsula in the northern Aegean, was paramount in this process. Unlike the Russian foundations in Palestine, the Russian monastic community on the Holy Mountain had a long history apart from government initiatives. The spiritual aspirations of the common people (narod) supported by the tsars and governing elite provided the material foundation for Russia's presence on Mt. Athos. The case of Mt. Athos, on one hand, further demonstrates the continuing relevance of religion in the Russian-Ottoman-Balkan relationship. On the other hand, the case of Mt. Athos suggests ways in which popular spirituality could influence diplomacy in relation to the Eastern Question. Mt Athos, due to its important geographical location on the southern coast of Macedonia, and due to its spiritual significance for the Eastern Orthodox world, was the centre of attention for all the states interested in the future division of the Ottoman Empire.

Mt. Athos, the eastern part of the Chalkidiki Peninsula, was one of the most important spiritual centers of the Eastern Christian world beginning in the $10^{\text {th }}$ century. It was a unique monastic republic. Under Byzantine rule, the ecumenical patriarchs had usually been Greek. Because the highest spiritual authority on Mt. Athos was the Patriarch of Constantinople, it is not surprising that most of the monasteries on Mt. Athos belonged to the Greeks. Although the Greeks dominated, many Orthodox peoples (Georgians, Bulgarians, Serbs, Rus/Russians, and later Romanians) had their own monasteries on Mt. Athos. Up until the $15^{\text {th }}$ century when the Ottomans conquered the Balkans, the monasteries were under the protection of either the Byzantine emperor or the monarchs of the respective Orthodox states to which the monasteries belonged. Mt. Athos thus presented a spiritual model of the Eastern Christian world, reflecting the political and cultural processes within it. The privileged and isolated position of Mt. Athos was due to the so-called abaton (the prohibition of women and alien persons-lay, military) and the large donations from Eastern rulers. Mt. Athos enjoyed an autonomous government and the monasteries became influential spiritual and cultural centers. The sultans preserved the privilege of self-government after the Ottomans conquered Mt. Athos in 1423-24.

Though the position of the church changed fundamentally under Ottoman rule, Mt. Athos continued to be a focus of religious aspiration for many Orthodox Christians. During the $16^{\text {th }}$ and $17^{\text {th }}$ centuries, the monasteries of the Holy Mount received large donations from the hospodars (rulers) of the principalities of Moldavia and Wallachia and from the Russian tsars. However, they also became victims of robbery and the despotic actions of Ottoman authorities. Little by little, the non-Greek monaster- 
ies fell into the hands of Greek monks, a process that reflected the situation in the Orthodox church in the whole of the Ottoman Empire. ${ }^{303}$

In the $18^{\text {th }}$ century, according to the account of the traveler, Vasilii Barskii, only a few Russian monks could be found on the Holy Mount. ${ }^{304}$ However, in the mid$19^{\text {th }}$ century, the Russian Monastery of St. Panteleimon and the two sketes-the Holy Prophet Elias and the Holy Apostle Andrew-grew. The prosperity of Russian monasticism on Mt. Athos in the late $19^{\text {th }}$ and early $20^{\text {th }}$ centuries is usually connected with two major persons, the confessor of the Russian monastery, Hieronym, and its abbot, Makarii Sushkin. ${ }^{305}$ Following the Russo-Turkish War of 1877-78, Russian monastic communities grew rapidly due to the protection of high diplomatic and governmental officials and the raising interest among the Russian people. In fact, they soon became the richest and most populated on the rocky peninsula.

Despite the disappointment of the Congress of Berlin, Russia insisted on including article No. 62, which provided important diplomatic patronage for the non-Greek monks on Mt. Athos. This crucial point guaranteed the autonomous existence of a Russian community in Ottoman territory under Russian state protection.

The spiritual flourishing of Russian communities on Mt. Athos inspired admiration among Russian pilgrims and travelers, who began to flock to the region in large numbers. The former patriarch, Joachim III, who lived on Mt. Athos in the years 18861901, stressed the difference between the Russian institutions and the Greek ones. “The spiritual power on Mt. Athos doesn't matter at all," he wrote to the Russian consul to Thessaloniki, Ivan S. Iastrebov. "Disobedience is rampant. The Greek monasteries are at odds with each other and are trying to surpass each other in willfulness. In contrast, order prevails in the Russian communities; everybody obeys the abbot, they work with humility and deny the self, and they don't interfere in lay affairs.”306

The prosperity of the Russian monasteries and sketes provoked discontent and envy among the Greeks, whose monasteries suffered from lack of financial support.

303 The scholarship on Mt. Athos is enormous. Useful guides include, I. Doens, Bibliographie de la Sainte Montagne de l'Athos (Mt. Athos: Agioreitiki Vivliothiki/Bibliothèque Athonite, 2001); D. Papachrysanthou, Athonikos monachismos. Arches kai organosi (Athens, Morphotiko Idryma Ethnikes Trapezes, 1992). 304 V. Grigorovich-Barskii, Pervoe posescheniie svaitoi Afonskoi gory Vasiliia Grigorovicha-Barskogo, Im samim opisannoe (St. Petersburg: Pravoslavoe Palestinskoe Obshchestvo, 1885).

305 On the Russians on Mt. Athos, see A. A. Dmitrievskii, Russkie na Afone. Ocherk zhizni i deiatel'nosti igumena russkogo Panteleimonova monastyr'a sviashchenno-arhimandrita Makariia (Sushkina) (St. Petersburg: Pravoslavoe Palestinskoe Obshchestvo, 1895); N. Fennell, The Russians on Athos (Oxford: Berg, 2001); Ierom. Ioakim (Sabel'nikov), Velikaia strazha. Zhizn' i trudy blazhennoi pam'ati afonskikh startsev ieroshimonakha Ieronima i shiarkhimandrita Makariia. Kn. i. Ieroshimonakh Ieronim, staretsdukhovnik Russkogo na Afone Sviato-Panteleimonova monastyria (Moscow: Izdatel'stvo Moskovskoi Patriarkhii, 2001); P. Troitskii, Istoriia russkikh obitelei Afona v XIX-XX vekakh (Moscow: Indrik, 2008); L. A. Gerd, Russkii Afon 1878-1914. Ocherki tserkovno-politicheskoi istorii (Moscow: Indrik, 2010); N. Fennell, P. Troitskii, M. Talalai, Il'inskii skit na Afone (Moscow: Indrik, 2011).

306 I. S. Iastrebov to A. I. Nelidov, January 24, 1891, RGIA, f. 797, op. 61.2 otd. 3 st., d. 146, 1l. 8-12. 
The general adverse conditions in the Balkans, and the intensity of nationalist passions and anti-Slav prejudices, promoted further hostility on the Holy Mount. The government of Athens repeatedly undertook measures against the Russian monastics. In 1883, a delegation of a theologian and historian, professors N. Damalas and P. Pavlidis, arrived from Athens. They proposed several ways to strengthen the Greek position on Mt. Athos. Firstly, they proposed that the patriarch be convinced to resist the pressure of Russian diplomacy and to act independently. They also proposed strengthening Greek education on the Holy Mountain in order to encourage the monks to protect the rights of the Greeks, and sending a Greek consul from Macedonia to Mt. Athos at least once a year to support the nationalistic sentiments of the monks. The Greek delegation further suggested that Greek pilgrimages to Mt. Athos be organized, to counterbalance the Russian ones which totaled as many as 4,000 pilgrims a year. Finally, the project proposed a scheme to grant Athonite monks British citizenship in order to benefit from British protection. If this latter point should prove difficult, continued Damalas and Pavlidis, "we should encourage the arrival of more monks who are English citizens, for example from Cyprus." ${ }^{307}$ Though this plan was never realized, it testifies to Greek concern about Russian influence on Mt. Athos as well as the British influence on Greek policy at that time.

The Greek consul to Thessaloniki, G. Dokos, who visited Mt. Athos in 1887, wrote a lengthy report to the Greek minister of foreign affairs, Stephanos Dragoumis, analyzing the situation on the Holy Mount from the point of view of Greek national interests. In his report, Dokos paid special attention to the Russian threat, and suggested that the leasing of buildings in Mt. Athos's capital, Karea, should be prohibited. He also believed that the stationing of diplomatic representatives there would be expedient. "We must have able people in every monastery," stressed Dokos. "By systematic work from one center we can neutralize the activities of the Russian monasteries, which are well protected. The Russian monks have one purpose in mind: they are organized with military discipline and serve [Russian] political centers abroad." ${ }^{308}$ It is interesting to note that among the measures that could be used against the Russians, Dokos did not exclude help from Roman Catholic states. In fact, he observed that the Austrian consul to Thessaloniki showed interest in the former italian monastery of the Amalfitani, known as Morfanou. The consul was curious to find some documents concerning this monastic settlement, which had ceased to exist centuries earlier. Dokos believed that establishing a Catholic monastery on Mt. Athos was unlikely, but the support from a great power like Austro-Hungary could be useful against the Russians. ${ }^{309}$

307 Ch. Kardaras, I politiki drasi tou Patriarhou Ioachim G' (proti patriarchia 1878-1884). (University of Ioannina: Doctoral dissertation, 1993), 253-58.

308 T. Dokos to S. Dragoumis, August 24, 1887, Archeion Gennadion/Archeion St. Dragoumi, f. 32.1 (Athos-Mones Agiou Orous), 1-26. The report was edited following a copy in the Archive of the Greek Ministry of Foreign Affairs: I. A. Papaggelos, “Ekthesi tou proksenou G. Dokou peri tou Agiou Orous (1887)”, Hronika tis Halkidikis, 40-41 (1985-86): 67-125.

309 Report from August 5, 1889, ibid. 
As the reports indicate, Greek diplomats feared that the Russian government was interested in Mt. Athos as a political and even military base. Indeed, St. Petersburg spared no expense in strengthening the Russian element there.

It appears that the general aim of Russian church policy in the Near East at this time was to pacify and reconcile the Orthodox peoples under the power of a supranational Ecumenical Patriarch. The Greek monks on Mt. Athos are here categorized as part of the general grouping 'Greeks' in Ottoman lands, and according to the report they should not serve as a pawn of the Athens government in its political ambitions. In fact, the Russian diplomats distinguished well enough the Greek monks of Ottoman origin, who usually were more open to supranational ecumenical views, and those who had come from the Greek kingdom and were typically influenced by nationalism.

The increasing number of Russian monks and pilgrims on Mt. Athos prompted the Russian government to appoint a representative to control the situation. Up to 1889, Abbot Makarii fulfilled this role, but after his death, the question about appointing a leader to supervise the flood of pilgrims arose again. Government officials in St. Petersburg, who were afraid of creating on Mt. Athos the same conflict and complicated situation that they had at the Russian spiritual mission in Jerusalem, did not support opening a Russian consulate on Mt. Athos or sending an ecclesiastic representative there. ${ }^{310}$

Based on the inconsistent instructions of the Russian Foreign Ministry, one can see that the Russian government had no clear policy when it came to Mt. Athos; it exhibited no definite position regarding the usefulness of the Russian presence there at all. The Russian embassy in Constantinople as well as the consulate in Thessaloniki sent numerous inquiries to the Russian Foreign Ministry concerning Mt. Athos, but never received concrete answers. Many of the diplomats strongly opposed investing further in Russian Mt. Athos (an idea posed earlier by the Metropolitan of Moscow, Filaret Drozdov) because they saw little benefit returning to Russia, both materially and spiritually. They argued that such resources would be better used to strengthen Russia's hold on the peripheries of the Russian Empire itself by supporting such institutions as the recently established Monastery of New Mt. Athos in the Caucasus. Realizing the need for a concrete decision, the Russian ambassador to the sublime porte, Nelidov, could not suggest a solution because nobody would donate such sums of money for this new venture. ${ }^{311}$ "We have only evidence of the deep reverence of the Russian people for the Holy Mount and cannot weigh the moral advantages of this

310 On the Russian foundations in the Holy Land, see N. N. Lisovoi, ed., Rossiia v Sviatoi zemle. Dokumenty i materialy, 2 vols. (Moscow: Mezhdunarodnye otnoshenia, 2000); N. N. Lisovoi, Russkoe duhovnoe i politicheskoe prisutstvie v Sviatoi Zemle i na Blizhnem Vostoke v XIX-nachale XX v. (Moscow: Indrik, 2006); Nikodim Rotov, archim., Istoriia Russkoi Dukhovnoi missii v Ierusalime (Serpukhov: Serpukhovskii Vysotskii Muzhskoi Monastyr, 1997).

311 Nelidov means the monastery of St. Simon Kananitis called "New Athos," founded in Abkhasia in 1875 by the Russian monks of St. Panteleimon Monastery on Old Athos. 
veneration or to what degree Mt. Athos is useful for us from a political point of view ... We must deal with an unknown, the independent and mighty national force [that is, the reverence of Russia's peasants]", wrote Nelidov. ${ }^{312}$ Nelidov believed that the Russian government should step back from influencing the affairs of Mt. Athos and should cease coordinating the flood of Russian pilgrims to Mt. Athos. Nevertheless, St. Petersburg consistently tried to limit the flow of money to Mt. Athos that Russian monks, especially kelliotes (inhabitants of the small cells that belonged to the big monasteries and that could therefore, never be regarded as Russian property) collected throughout Russia.

The legal status of the Russian monks on Mt. Athos remained uncertain as the surge in pilgrims coincided with major political and legal changes taking place in the Ottoman Empire at this time. According to the Mt. Athos Regulations (Kanonismos) of 1876 (included in the Turkish Law Code), all Mt. Athos monks, irrespective of their nationality, were regarded as Ottoman citizens. They were given a sort of residency permit (nufus in Turkish) but in fact, their Turkish citizenship remained nominal. The Russian monks, however, also maintained their Russian passports and enjoyed diplomatic protection according to Article 62 of the Berlin Treaty of 1878. Russian law stipulated that a person could lose his or her nationality by serving a foreign state without the permission of his government, or by refusing to return to Russia when summoned by the government. However, according to the edict of the Russian Holy Synod of July 13, 1816, Russian subjects who became monks abroad were not recognized as monks inside Russia. Furthermore, Tsar Alexander I issued another law which allowed Russian citizens to become monks abroad on the condition that they would never return to their motherland. ${ }^{313}$ Later persons who had become monks abroad could join Russian monasteries after spending three years as novices; in every case, permission from the Holy Synod was necessary. The dual status of the Russian monks-having both Russian and Ottoman citizenship-on Mt. Athos was both advantageous and disadvantageous for them. On the one hand, it allowed them to conduct monastic business in Russia; on the other hand, governmental officials could choose to protect them only when they found it advantageous; if a certain monk was regarded as "unreliable," the formula "such person calls himself a hieromonk," was employed to discredit him. In some cases, Russian diplomats did not hesitate to dismiss the most importunate applicants because they were "Turkish citizens." 314

The Turkish authorities made several efforts to strip Russian monks of their Russian status, but these efforts were always foiled by Russian diplomacy. While

312 A. I. Nelidov to N. P. Shishkin, April 10, 1890, AVPRI, f. 180, op. 517/2, d. 1193a, 11. $292-95$.

313 Pribavleniia k Tserkovnym Vedomostiam, (February 11, 1917): 134; ibid., (February 18, 1917): 161.

314 For example, in 1879 Ambassador A. B. Lobanov-Rostovskii rejected to help the Georgian monks on the reason that they, having become monks abroad, had lost their Russian citizenship. See, AVPRI, f. 180, op. 517/2, d. 3672, 11. 11-12. 
conducting the census of the Mt. Athos population in 1905, for example, the Turkish authorities tried to confiscate the passports of Russian monks. The demand of the officials, however, met with resolute refusal from all Russian monasteries except the Georgian cell of St. John the Theologian. These monks surrendered their passports. But upon the protest of the Russian representative in Thessaloniki, Nikolai V. Kokhmanskii, the vali (governor) of the city promised to return the passports. ${ }^{315}$ In the face of the resistance of the monasteries, the Turkish authorities backed down rather than create an international scandal. After a new wave of confiscations of Russian monks' passports by the Young Turk government in 1909, Kokhmanskii again stressed to the government that the Russians on Mt. Athos were regarded as only temporarily outside Russia and had never lost their citizenship. The Russian consulate in Thessaloniki issued new passports to replace the confiscated ones, treating the passports as lost rather than confiscated in order to placate the Turkish authorities. ${ }^{316}$

At the beginning of the $20^{\text {th }}$ century, the issues occupying Russia in regard to its presence on Mt. Athos had not changed. The fears concerning Russian expansion on the Holy Mountain and its final transition into Russian hands are reflected in the report of the Bulgarian agent in Thessaloniki, Atanas Shopov:

I travelled from monastery to monastery around the whole Mt. Athos peninsula and it seemed to me that I'm travelling around Russia. Continually on the quays, in the monasteries, in the cells, in the centre of the kaza [the administrative district of Mt. Athos], in forests and on roads you meet Russians and more Russians, both monks and laity. Their number is increasing from day to day ... in five or six years the number of Russians will have doubled or tripled. Nobody doubts that in a few years only Russians will inhabit the whole of the Holy Mountain. The Russians, but also the Greeks and Bulgarians suppose that soon the Mt. Athos peninsula will politically be governed by Russia as well. Economically it has been in Russian hands for a long time. All the rich Greek monasteries receive their incomes from Russia which controls the receiving and distribution of these revenues. ${ }^{317}$

In 1898, the Russian consul to Thessaloniki, N. A. Ilarionov, visited the Serbian Hilandar Monastery. Hilandar, one of the oldest monasteries on the Holy Mountain, had large debts and a very small monastic population. Only a few of the monks were Serbian; most were Bulgarians from Macedonia. The Russians had had their eye on this monastery for a while and offered to pay its debts in exchange for allowing one or more Russian monks into the brotherhood; in this way, it was hoped, the monas-

315 N. V. Kokhmanskii to I. A. Zinoviev, November 1, 1905, AVPRI, f. 180, op. 517/2, d. 3679, 1l. 2-3. 316 N. V. Kokhmanskii to N. V. Charykov, August 29, 1909, ibid., 1. 8; N. V. Kokhmanskii to N. V. Charykov, August 29, 1909, ibid. 1. 9; a note by N. V. Kokhmanskii, Constantinople, September 11, 1909, ibid., 1l. 6-7; N. V. Charykov to A. M. Petriaev, October 15 1909, ibid., 1. 5.

317 A. Shopov to I. S. Geshov, May 22, 1900, Centralen Dyrzhaven Archiv (CDA Sofia, Bulgaria), f. 321k, op. 1, d. 1480, 11. 69-70. 
tery would gradually pass into Russian hands. ${ }^{318}$ The Serbian government, however, took measures to counter Russian influence and strengthen the Serbian presence at Hilandar. In 1900, Belgrade paid the debts of the monastery and offered to grant it an annual sum of 1000 Ottoman liras. ${ }^{319}$ In the end, the Russian consul decided to support the Serbs in Hilandar rather than increase Russian presence, which was in keeping with the general policy of the Russian government in Macedonia during these years, i.e. to support the Serbs against the Bulgarians, although Russia did not abandon its goal of acquiring the monastery.

The Russians occupied several cells belonging to Hilandar, the largest one being the cell of St. John Chrysostom. In 1902, an agreement was signed between the abbot of the cell and the Serbian metropolitan of Rashka and Prizren. According to this agreement, the metropolitan passed authority over the Lavra of Dechani in Kosovo, which had historically been Serbian, to the Russians for several years. In exchange, the Russians agreed to organize a strict monastic order, to restore the buildings and to protect the monastery from attacks by Albanian brigands. While for the Serbian ecclesiastical authorities this measure was the only way to save the monastery, for the Russian monks it was an opportunity to found a new Russian monastery in the Balkans. The Russian abbot intended to organize the Dechani monastery as an extension of the cell of St. John Chrysostom, which would not be limited in the number of the monks nor in the scope of building initiatives. In the following years, about twenty Russian monks were installed in Dechani. ${ }^{320}$

Simultaneously, Russian monks from Mt. Athos explored other options for their creative activities, namely in Palestine and Syria. Many small, neglected monasteries existed in this region which could be easily bought by rich Russian kelliots. In 1903, the abbot of the Russian cell of the Holy Cross on Mt. Athos, Panteleimon, purchased the ancient Lavra of St. Chariton, eight kilometers from Jerusalem, and settled seven monks there. ${ }^{321}$ The Patriarch of Jerusalem, Damianos, protested that this was uncanonical interference into the affairs of another church, but the Russians ignored the patriarch's letter. On July 12, 1912 in Damascus, the Patriarch of Antioch, Gregorios, and a representative of the cell of the Holy Cross on Mt. Athos, Gennadii, signed an agreement that enabled Russians to lease the patriarchal monastery of St. Ilias Shuaya in Syria. The Russian abbot of the Mt. Athos cell was appointed as abbot of the monastery. According to the agreement, the Russian brotherhood became owners in perpetuity of all the movable and immovable property of the monastery and had to make graduated payments to the patriarch, which increased from 200 to 400 French

318 Ibid., 11. 66-71.

319 A. Shopov to T. Ivanchov, April 19, 26, and 27, 1900, ibid., 11. 4-5, 20-21, 26.

320 See more about this in Chapter 6.

321 For the documents on this affair, see "Lavra prepodobnogo Kharitona ispovednika (Ain-Farskoe delo) (1904-1914 gg.)” in N. N. Lisovoi, ed., Rossiia v Sviatoi Zemle, ed. Lisovoi, 2: 302-28. 
napoleons a year. The Russian consul to Damascus considered this a favourable arrangement both for the strengthening of Orthodoxy in Syria and for the Russian convent. $^{322}$

Irrespective of the political significance of such initiatives, the main reasons for the Russian monks' interest in Palestine were the lack of space and opportunity for development on Mt. Athos. The richest Russian cells would have been able to take in a large number of monks and to build large monasteries, but Athonite regulations strictly forbade such expansion. However, the Russians did not always adhere to the restrictions and such actions led to constant conflicts between Russians and Greek ecclesiastical authorities. The kelliots posed one of the main problems on Mt. Athos in the beginning of the $20^{\text {th }}$ century, both for the Greeks and Russians. Officially, no more than three monks could live in each cell, one senior and two younger. But in fact, within a few years the senior monk often gathered money to take on more novices and rebuild the cell into a more substantial and prosperous settlement. The population of such cells sometimes grew to more than one hundred persons; some were able to build magnificent churches and monastic houses. This development made the dependent cells, the inhabitants of which were only tenants, de facto monasteries sometimes richer than their parent monastery.

In 1896, the Mt. Athos kelliots united and founded an organization, “The Brotherhood of Russian Kelliots". ${ }^{323}$ The organization aimed to protect the rights of the kelliots in their struggle with the major Greek monasteries. Soon the Brotherhood managed to attract the favorable attention of the Russian royal family and support from the ambassador in Constantinople, Zinoviev, as well as the influential director of the Russian Archaeological institute in Constantinople, T. I. Uspenskii. The Brotherhood kept a hospital in Thessaloniki and a monastic school in the Ottoman capital.

While the kelliots enjoyed support from some diplomats and high officials, the Russian Holy Synod did not look on them with favour. It was easier for church authorities to deal with the big monasteries than with independent settlements. The Synod feared that the legal disputes between smaller Russian settlements and large Greek monasteries would continue for decades and cause serious difficulties. The Russian Holy Synod therefore issued decrees against the kelliots' and monks' letters request-

322 Shahovskoi to the Russian Holy Synod, 1912, RGIA, f. 796, op. 195, VI otd. 1 st., d. 1116, 1. 4.

323 Kelliots were the inhabitants of the small monastic huts called "kellion" (cell, the third and smaller form of settlement behind the monasteries and the sketes). These foundations belonged to some of the large independent monasteries and monks could only lease them. The Athos Regulations provided a limitation of six inhabitants for the kellia, who were regarded as hermits. Nevertheless, the Russian monks established a much larger number of monks there and built large churches and edifices. The organization of the brotherhood made the kelliots a power comparable to St. Panteleimon Monastery. Their activities were a matter of constant controversies with the Greek owners of the kellia. See, P. Troitskii, Istoriia russkikh obitelei Afona v XIX-XX vekakh (Moscow: Indrik, 2009), 111-88. 
ing economic support, which had been sent throughout Russia. ${ }^{324}$ The large Russian monasteries and some public authorities supported the position of the Russian Synod. For example the famous liturgist at the Theological Academy in Kiev, Alexei Dmitrievskii, wrote a passionate article against the kelliots' activities. ${ }^{325}$ Obviously, such criticism directed towards a significant portion of the Russian monks would not contribute to the stability of the Russians on the Holy Mountain as a whole. Dmitrievskii's article also caused a sensation in Greece after being translated by the secretary to Meletios Metaksakis, the Archbishop of Cyprus and later Patriarch of Alexandria and of Constantinople, who used it in his extremely Russophobic book. ${ }^{326}$ Encouraged by the position of the Russian Synod, the Patriarch of Constantinople issued a decree limiting the size of the kelliots and their number on Mt. Athos. ${ }^{327}$ Despite these measures, the kelliots continued their activities.

In the dangerous and stormy situation in the Balkans in the first decades of the $20^{\text {th }}$ century, the rich Russian monks who lived without protection increasingly became victims of thefts and robbery. The Russian diplomats during their frequent visits to the Holy Mountain tried to protect the kelliots. From the reports of the employees of the embassy and the consulate in Thessaloniki we can find that they usually sympathized with the kelliots and stressed that with some rare exceptions they were pious people who cared only about saving their souls. ${ }^{328}$ This provides an example of the contrast between the actions of the Russian Foreign Ministry and the Holy Synod; here, the Russian government proved more supportive of monks on Mt. Athos than did the Russian Orthodox Church.

A new era in the life on Mt. Athos began with the Balkan Wars. In November 1912, the Greeks annexed the Holy Mountain. A Greek army detachment of 800 soldiers formed a garrison; the Bulgarians also sent 70 soldiers to protect their monastery. While the Greek inhabitants of Mt. Athos regarded this as a liberation making possible a resurgence of their influence, the Slavs were rather anxious about their future. The status of Mt. Athos was a matter of international discussion at the London Conference of 1912-13. Russia categorically insisted on the internationalization of Mt. Athos under the protectorate of the six Orthodox states (Russia, Greece, Serbia, Romania,

324 "O merakh dlia bor'by s zloupotrebleniami afonskikh kelliotov po sboru pozhertvovanij v Rossii," Tserkovnye vedomosti, April 30, 1911, no. 18, pribal'eniia, razdel "Khronika".

325 A. A. Dmitrievskii, Russkie afonskie monakhi-kellioty i ikh prositelnye o milostyni pis'ma, rassylaemye po Rossii. Rech, proiznesennaia pri otkrytii chtenii v Kievskom religiozno-prosvetitel'nom obshestve 9 oktiabria 1905 g. (Kiev: Kievskaia Dukhovnaia Akademiia, 1906).

326 G. Papamihail, Apokalipseis peri tis Rosikis politikis en ti Orthodoxi Anatoli (Alexandria: n.p. 1910); Meletios Metaxakis, mitr. Kritiou, To Agion Oros kai i Rosiki politiki en Anatoli (Athens: n.p. 1913).

327 Patriarchikon sigillion peri kelliotikou zitimatos ekdothen epi tis patriarheias tou Panagiotatou Oikoumenikou patriarhou k. Ioachim G' tou apo Thessalonikis (Constantinople: n.p. 1909).

328 N. Kokhmanskii to I. A. Zinoviev, April 30, 1906, AVPRI, f. 180, op. 517/2, d. 3680, 11. 1-6, 7, 8-9; May 8, 1907, RGIA, f. 797, op. 73, II otd. 3 st., d. 293, 11. 18-19; May 21, 1912, AVPRI, f. 180, op. 517/2, d. 3682, 11. 7-9. 
Montenegro and Bulgaria). The first goal was to neutralize Greek supremacy, and the second, to protect the rights of the monks native from each Orthodox state. Had the Greeks succeeded in dominating Mt. Athos, all the contentious issues would have been resolved in favour of the Greeks, and not the Russians. In the Russian plan of a protectorate, not surprisingly, international control of the Orthodox states over the Holy Mountain would ensure Russia's dominance.

Russian diplomats developed several options for dealing with the matter of jurisdiction. The consul to Thessaloniki, Alexei K. Beliaev, proposed that each of the six Orthodox states appoint one representative, who would have a seat in Karea, the administrative center of Mt. Athos. The delegates would comprise an official council with the Russian representative as chairman. This council would be the only representative of Mt. Athos in its international contacts. The delegates would function in the same capacity as the consuls of the Great Powers did in the Ottoman Empire. According to Beliaev's plan, the Mt. Athos monastic population would be dependent politically on the Russian Foreign Ministry. The spiritual authority of the Patriarch of Constantinople and the self-government of Mt. Athos in its internal affairs would remain as before. ${ }^{329}$ Another proposal, developed by the Russian consul to Monastir, A. M. Petriaev, repeated, in general, the main points articulated by Beliaev. ${ }^{330}$

The proposal of B. S. Serafimov, the adviser on ecclesiastical affairs in the Russian embassy in Constantinople, further enhanced the degree of tsarist protection. ${ }^{331}$ Serafimov stressed that since the non-Russian monasteries existed due to incomes from their estates in Russia or the collection of money there, he concluded that without Russian aid they would soon be in dire straits. Serafimov emphasized that there were 4,250 Russian monks on Mt. Athos in 1909-11, without taking into consideration the metochs (farmsteads), and he advocated expanding Russian influence on Mt. Athos. "One can hope that with the change of political circumstances the present situation will change as well. In due course many of the 17 Greek monasteries will become Russian, as had happened with the Monastery of St. Panteleimon, and then our monks will consider themselves to be in better conditions," he wrote. ${ }^{332}$ Russia itself would deal with all Mt. Athos affairs giving the monks the opportunity for internal self-government according to the ancient rules. The representatives of the other five Orthodox states would also send their representatives to serve as consuls. One can notice that this proposal was hurriedly written and was not free from political romanticism.

The legal adviser of the Russian embassy in Constantinople, A. N. Mandelshtam, discussed the juridical side of the issue in detail. He advocated either designat-

329 AVPRI, f. 180, op. 517/2, d. 3686, 1l. 1-4.

330 Ibid., 11. 5-9.

331 Ibid., 11. 20-27.

332 Ibid., 1. 25. 
ing Mt. Athos as a neutral territory under the protectorate of the six Orthodox states or making it a neutral territory governed by representatives of the six states. ${ }^{333}$ In his opinion, the creation of a neutral territory was preferable for Russia because this would allow Russian laws to be implemented. Mandelshtam maintained that in either case a strong governmental power was obligatory in order to stop the international disagreements on the Holy Mountain. The nationalistic tensions between Russians and Greeks, Greeks and Bulgarians, Greeks and Georgians were a reflection of the general GreekSlav (and Greek-Georgian) tension in the Balkans in those years. The Second Balkan War and the defeat of Bulgaria made the situation on Mt. Athos more acute.

When the monks on Mt. Athos learned of the Russian plans to internationalize and establish a condominium, the seventeen Greek monasteries sent their delegates to the Athens government and to the London Conference with a petition to unite Mt. Athos with the Greek kingdom. At the same time, the Russian monks addressed another petition to the London Conference demanding the neutralization of Mt. Athos under the protectorate of Russia and the Balkan states. in their petition, they asked that one representative for every 250-300 monks be sent to the central council; that civil and criminal matters be separated from spiritual ones; that the present rules on possession of landed estates be abolished and that these estates remain in Russian hands after the leases expired rather than being returned to their Greek owners. ${ }^{334}$

The question of the international status of Mt. Athos was not solved during the deliberations at the London Conference. The London Treaty of May 17, 1913 only postponed the decision regarding the Holy Mountain. In July and August of 1913, ambassadors of the Great Powers held a meeting in London to discuss the consequences of the Balkan Wars; the status of the Holy Mountain numbered among the issues discussed. The Austro-Hungarian representative strongly opposed the Russian proposal to make Mt. Athos neutral because at that time, the Hapsburg Empire, more than any other power, had a vested interest in southern Macedonia. Because of Austro-Hungary's opposition, only the first part of the proposal concerning the preservation of the spiritual subordination of Mt. Athos to the patriarch was adopted. As for the proposal to form a common protectorate, it was postponed due to irreconcilable disagreements among the parties. The Treaty of Bucharest signed on August 26, 1913, also did not resolve the problem.

The Second Balkan War and the defeat of Bulgaria buried all hopes for a union of Orthodox states or of Slavic states under a Russian protectorate. The Bulgarian ecclesiastical schism could not be mended and a common protectorate on Mt. Athos seemed unlikely. The resistance of the western powers was not the only obstacle. In June and July of 1913, another internal problem arose on Mt. Athos, namely the matter of the Name Worshipers (Imiaslavtsy or Imiabozhniki). The followers of the movement

333 AVPRI, f. 180, op. 517/2, d. 3689, 11. 1-21.

334 Ibid., d. 3686, 1l. 29-36. 
accepted the idea that "the Name of God is God Himself”. The roots of this heresy lay in the Byzantine mysticism of Symeon the New Theologian and Hesychasm, a $14^{\text {th }}$ century renewal movement led by St. Gregory Palamas. The continual repeating of the Jesus Prayer ("My Lord Jesus, have mercy on me") was an age old tradition on Mt. Athos so Name Worshippers were not so much inventing a modern heresy as reinterpreting an old tradition. ${ }^{335}$ This movement, being purely spiritual, split the Russian monastic community in half. The Russian government, weary of further complications in the Balkans, mistook the disturbances for political action and regarded the movement as a rebellion. The Greek monasteries and the patriarch wanted to deport a part of the Russian monastic community, and supported the Russian ecclesiastical and civil authorities. In July 1913 more than 800 Russian monks were forcibly relocated to Russia. This action marked the beginning of the weakening of the Russian element on Mt. Athos.

In September 1913, as the international status of Mt. Athos remained uncertain, a representative of the Russian embassy in Constantinople, Serafimov, arrived on Mt. Athos on a special mission. The aim of his visit was to brief the embassy on the situation, protect Russian monks from violations, and work to restore peace on the Holy Mountain. In the same month, the Metropolitan of Cyprus, Meletios Metaksakis arrived on Mt. Athos to spread agitation among the Greek monks and support their nationalistic aspirations. The presence of Serafimov (who despite his being incognito was regarded as a Russian consul), irritated the Greek monks to a considerable degree. At the end of September, the Kinot (the Mt. Athos administration body) decided to move him from the Skete of St. Andrew. This decision, however, was not implemented because of the uncertain position of the Vatopedi Monastery, which housed the Skete, and which was afraid it would lose income from its estates in Bessarabia if Serafimov would complain about his removal to the Russian Ministry. Meanwhile, the Greek press printed angry articles against Serafimov. ${ }^{336}$

In October 1913, the Kinot of Mt. Athos together with Metropolitan Meletios wrote a petition to the Greek king Constantine expressing its desire that the Holy Mountain be included as part of the Greek kingdom to ensure that no civil authority could inter-

335 The stimulus for its spreading was the book Na gorakh Kavkaza by Hieromonk Ilarion. The leader of the movement became monk Antonii Bulatovich, a former officer. The Name Worshipers followed the Byzantine practice of the hesychast and in fact had no political inspirations. On this topic, see the excellent work by Ep. Ilarion Alfeev, Sviashchennaia taina Tserkvi. Vvedeniie v istoriiu i problematiku imiaslavskikh sporov (St. Petersburg: izdatel'stvo Olega Abyshko, 2007); see also, K. K. Papoulidis, Oi Rossoi Onomatolatrai tou Agiou Orous (Thessaloniki: IMXA, 1977); L. Graham, J. M. Kantor, Naming infinity: A True Story of Religious Mysticism and Mathematical Creativity (Cambridge: Harvard University Press, 2009), 7-18.

336 Reports of B. S. Serafimov to M. N. Giers, September 24, 1913; October 1, 1913; October 7, 1913, AVPRI, f. 180, op. 517/2, d. 3697. 
fere in its affairs. ${ }^{337}$ The representatives of the Bulgarian and Serbian monasteries, intimidated by the Greeks, also subscribed to the petition. Only the representative of the Russian St. Panteleimon Monastery refused to subscribe. The petition was publically read in the presence of many monks on October 3, a national holiday for the Greeks, was accompanied by a ceremony and prostration before the icon Axion Estin, with claims of 'Long live Greece!' Metropolitan Meletios also gave a passionate patriotic speech. ${ }^{338}$ A delegation of five representatives visited King Constantine and Prime Minister Eleftherios Venizelos with the petition. The latter assured the monks that "as the Holy Mount has kept and keeps all the Byzantine rites, and has kept for us our language during the long ages of slavery, it is of great importance for Hellenism. Be sure, fathers, that the government will do its best to preserve the structure of Mt. Athos, both ecclesiastical and political". ${ }^{339}$ Both the king and the prime minister were ready to support the Greek monks on Mt. Athos.

During his stay on Mt. Athos, Serafimov continued to concentrate on the future international status of Mt. Athos. Metropolitan Meletios proposed that Russia should abstain from its program of internationalization, while Greece should guarantee that the Russian monks would have the rights and privileges that they had had before the Balkan Wars. In the present situation, Serafimov was inclined to adopt this proposal, because the establishment of an association of Orthodox states would be impossible to implement without undertaking violent measures and Greek counter-petitions to the Powers. Meanwhile, the Bulgarian Schism remained unresolved, and Serbia united with Greece to oppose Russian interests. Romania had only two sketes and several cells on Mt. Athos (which were hostile to the patriarchate), and Montenegro had no interests on the Holy Mountain. According to Serafimov, the protests of the Mt. Athos Greek Kinot would result in limiting Russian advancement towards the Archipelago and the Mediterranean which would stall Russia's efforts. This would be catastrophic for the Russian monasteries, while the adoption of the proposal of Meletios could "give us the opportunity to reach our intended results". ${ }^{340}$

Serafimov also presented the conditions on which, in his opinion, the RussianGreek agreement could be signed. Serafimov proposed that the Mt. Athos religious community would remain under the spiritual power of the Ecumenical Patriarch, and that all actions on Mt. Athos would be undertaken only after their approval by both Russian and Greek authorities. According to his proposal, a guard formed both by Greeks and Russians would replace the Greek military detachment, and the Greek

337 See the Russian translation of this text in addition to the report of Serafimov, October 21, 1913, ibid., 11. 46-47.

338 Reports of Serafimov, October 7, 1913, ibid., 11. 23-24, 34-35

339 An extract from the protocol of the session of the Kinot on October 28, 1913. Quoted from the report of B. Serafimov, November 2, 1913, ibid., 1l. 57-60.

340 Ibid., 11. 30-31. 
government should not confiscate monastic properties outside the peninsula (mainly in Macedonia and Thrace). The latter point, stressed Serafimov, had especial significance for Russia regarding the estate, Nuzla, in the Gulf of Kavala, which belonged to the Russian skete of St. Andrew, and which could be used as a strategic naval base. ${ }^{341}$ The proposal of Serafimov, though favourable to Russia, was not adopted by the Russian Foreign Ministry. Meanwhile, the position of Serafimov on Mt. Athos became more and more difficult and even dangerous. In December 1913 he left the Holy Mountain.

The question of the status of Mt. Athos continued to be discussed in 1914. Ever the artful and flexible diplomat, Greek prime minister Venizelos, who desired Russian support, was ready to make some concessions. In May 1914, the Russian ambassador to Constantinople, Giers, handed the Greek representative a proposal concerning the international status of Mt. Athos and expressed his willingness to begin negotiations. The agreement, based on Serafimov's plan, contained two main points: the spiritual subordination of Mt. Athos to the Ecumenical Patriarch and Russian control over the political administration of the monastic foundations. ${ }^{342}$ The Greek government put forward a counter-proposal about a Greek-Russian condominium on Mt. Athos. It proposed dual citizenship for Athonite Russian monks and restricted all other Orthodox states from taking part in decisions regarding the governance of Mt. Athos. ${ }^{343}$ This proposal might have been the better way out for Russia as a patron of Slav interests in the Balkans even though Greece would in all likelihood, renege on its promises once it had a firm hold on Mt. Athos. Its implementation, however, was thwarted due to the resistance of Serbia and Bulgaria.

With the onset of the First World War, the matter of the status of Mt. Athos did not come up again at a diplomatic level. Up until the Revolution of 1917, the Russian government did not recognize Mt. Athos as part of the territory belong to the Greek kingdom. We may definitely speak about the final union of Mt. Athos with Greece only in 1926, when the Greek government issued a law that all monks of the Holy Mount should be Greek citizens. Thus, the long discussions on the international status of Mt. Athos ceased immediately when Russia ceased its diplomatic pressure.

After the defeat of the Name Worshipers in 1913 and the beginning of the First World War the following year, when many of the novices were called up to military service, a rapid decrease in Russians on Mt. Athos began. From 1913 to 1917, the

341 Ibid., 11. 31-32.

342 H. K. Papastathis, "To kathestos tou Agiou Orous kai tis Ekklisias stin Makedonia meta tin synthiki tou Boukourestiou,” Nomokanonikes meletes (Athens: Protypes Thessalikes Ekdoseis, 2009), 61-63. 343 A secret telegram of M. N. Giers, July 13, 1914, AVPRI, f. 151, op. 482, d. 3877, 1. 13. See, O. E. Petrunina, "Afonskii vopros 1812-1917 gg. Po materialam russkikh diplomaticheskikh istochnikov," Vestnik archivista (2002) 1: 74. 
Russian population on Mt. Athos halved from 4100 to $2460 .{ }^{344}$ After 1917, when Russians lacked the opportunity to visit Mt. Athos and the government no longer supported the monasteries, Russian monasticism on the Holy Mountain ceased until the end of the $20^{\text {th }}$ century.

The period between the end of the Russo-Turkish War of 1877-78 and the beginning of the First World War was the "golden age" of Russian Mt. Athos. Despite the opposition from the Ecumenical Patriarchate and the Greek monasteries (as well as of the Russian government), the aspirations of the Russian people for a presence on Mt. Athos were so strong that the Russian monastic population grew annually. In the difficult political situation at the turn of the century, the Russian government did not take active steps in the Balkans; it maintained the status quo. The fear of breaking the balance of power and provoking a military conflict led to an extremely passive position on the part of the Russian Foreign Ministry, which preferred non-involvement on every occasion on this issue. Sometimes even the rational proposals of the diplomats met with no sympathy from the Holy Synod; many matters that had to be solved immediately were caught up in red tape.

The inconsistency of the policy towards the Russian monks on Mt. Athos meant that the political potential of Mt. Athos was not used to the full and did not bring the benefit it could. One could say that Russian Mt. Athos acted not in coordination with the governmental policy, but to some degree in spite of it. The enterprising, business-savvy Russian peasants, inspired by liberty which they could not receive in their motherland, created a unique phenomenon in southeastern Europe: a large Russian community with strong economic and moral potential. One cannot doubt that this original "Russian island" in the eastern Mediterranean served as a real support to the Russian authority in the region. It is difficult to say what the fate of the Russians on Mt. Athos would have been if the Revolution of 1917 had not happened. Yet, one thing is certain: Russian monasticism greatly influenced the political and spiritual life of the Balkans and of Eastern Christianity in general. Later, during the $20^{\text {th }}$ century, Russian learned monks from Mount Athos spread the knowledge about Orthodoxy in Western Europe.

344 M. G. Talalai, "Russkoe monashestvo na Afone 1913-1917 gg. Otchety A. A. Pavlovskogo v Rosiiskoe general'noe konsul'stvo v Salonikakh,” in: Rossiia i Khristianskii Vostok, II-III (Moscow: Indrik, 2004): 595-617. 